\title{
KONSEP PERLINDUNGAN PACU JALUR KABUPATEN KUANTAN SINGINGI
}

\author{
${ }^{1}$ Adi Tiaraputri, ${ }^{2}$ Ledy Diana \\ ${ }^{1,2}$ Fakultas Hukum Universitas Riau \\ Email: ${ }^{1}$ adi.tiaraputri@lecturer.unri.ac.id ${ }^{2}$ ledy.diana@lecturer.unri.ac.id
}

\section{Info Artikel:}

Diterima: 21 April 2020

| Disetujui: 23 Mei 2020

| Dipublikasikan: 30 Juni 2020

\begin{abstract}
Abstrak
Pacu jalur merupakan salah satu tradisi dari Kabupaten Kuantan Singingi Provinsi Riau. Pacu jalur juga termasuk dalam ruang lingkup kebudayaan. Untuk ada kelestarian kebudayaan tentunya harus ada perlindungan terhadap kebudyaan tersebut. Tulisan ini mengkali terkat konsep perlindungan yang dapat diberikan pada tradisi pacu jalur. Metode penelitian dalam tulisan ini melalui pendekatan yuridis normatif. Dalam tulisan ini mengkaji konsep perlindungan untuk pacu jalur dapat melalui perlindungan warisan budaya tak benda dan kekayaan intelektual komunal.
\end{abstract}

Kata Kunci: pacu jalur, warisan budaya tak benda, kekayaan intelektual komunal

\section{PROTECTION CONCEPT PACU JALUR KUANTAN SINGINGI REGENCY}

\begin{abstract}
Pacu Jalur is one of the traditions of Kuantan Singingi Regency, Riau Province. Pacu jalur is also included in the scope of culture. For there to be preservation of culture, of course, there must be protection of that culture. This paper examines the concept of protection that can be given to the tradition of racing lanes. The research method in this paper is through a normative juridical approach. In this paper, we examine the concept of protection for the runway through the protection of intangible cultural heritage and communal intellectual property.
\end{abstract}

Keywords: pacu jalur, intangible cultural heritage, communal intellectual property 


\section{A. PENDAHULUAN}

Pacu jalur adalah salah satu olahraga tradisional yang dikenal dari Provinsi Riau, salah satunya dari Kabupaten Kuantan Singingi. Tradisi pacu jalur sudah ada sejak masa penjajahan Belanda dimana tradisi ini untuk memperingati hari lahir Ratu Wihelmina (Ratu Belanda) yaitu pada bulan November ${ }^{1}$. Setelah kemerdekaan Indonesia, tradisi pacu jalur ditujukan untuk merayakan Hari Ulang Tahun Kemerdekaan Republik Indonesia ${ }^{2}$.

Tradisi pacu jalur adalah tradisi yang telah mengakar lama bagi masyarakat Kuantan Singingi. Jalur merupakan suatu hasil budaya, yang dikenal baik dalam masyarakat rantau Kuantan, dalam kurun waktu yang cukup lama. Daerah yang disebut rantau Kuantan sekarang ini ialah daerah sepanjang batang (sungai) Kuantan sekarang ini. Ke hulu batasnya Lubuk Jambi (Ibu Kota Kecamatan Kuantan Mudik) dan ke hilir batasnya sampai Cerenti (Ibu Kota Kecamatan Cerenti). Arti kata Jalur dalam dialek melayu bagi penduduk kampung batang kuantan cukup sulit untuk diberikan pembatasan. Menurut Kamus umum Bahasa Indonesia susunan W.Y.S Poewardarminta terbitan tahun 1966, tidak ada arti yang begitu cocok dengan jalur yang dimaksud oleh dialek

1 Hasbullah, dkk, Olahraga dan Magis: Kajian Terhadap Tradisi Pacu Jalur di Kabupaten Kuantan SIngingi, 2015, hlm 6. ${ }^{2}$ Ibid. melayu penduduk Rantau Kuantan. Tetapi kata jalur menurut kamus tersebut yang artinya "Barang Tipis Panjang" sehingga ada terasa hubungan dengan jalur yang dimaksud masyarakat Kuantan ${ }^{3}$.

Sebelum pelaksanaan pacu jalur diadakan, maka ditetapkanlah panitia pelaksananya. Panitia pelaksana harus menjamin terlaksananya pacu dengan baik. Biasanya panitia pelaksana selalu diprakarsai oleh camat bersama pemuka masyarakat. Tugas panitia pelaksana menentukan hakim mengurus arena pacu, mencari dana, mengatur segala hal-hal yang berhubungan dengan kegiatan pacu jalur mini, membuat undian, dan menyebarkan undangan. Dalam perlombaan pacu jalur tersebut, ada peraturan-peraturan yang harus ditaati oleh peserta lomba dan peraturan tersebut sangatlah diperlukan karena disamping nilai seni pacu jalur juga ada unsur- unsur olahraganya ${ }^{4}$.

Pacu jalur hanya dilakukan oleh para laki-laki yang berusia antara 15--40 tahun. Setiap regu jumlah anggotanya antara 40-60 orang (bergantung dari ukuran jalur). Anggota sebuah jalur disebut anak pacu, terdiri atas: tukang kayu, tukang concang (komandan, pemberi aba-aba), tukang pinggang (juru mudi), tukang onjai (pemberi irama di bagian kemudi dengan cara menggoyang-goyangkan badan) dan

${ }^{3}$ Ibid. 
tukang tari yang membantu tukang onjai memberi tekanan yang seimbang agar jalur berjungkat-jungkit secara teratur dan berirama ${ }^{5}$.

Peraturan dalam pacu jalur tersebut dipimpin oleh juri atau wasit haruslah diketahui oleh peserta, peraturan inilah yang mengikat anak pacu di gelanggang atau di arena pacu jalur, sehingga tidak terjadi keributan karena tabrakan atau sesuatu yang yang memicu keributan karena tidak adanya aturan salah satunya siapa yang mengambil jalan lawan walaupun jalur sampai di finis terlebih dahulu, jalur tersebut dianggap diskualifikasi. Regu jalur yang dapat mencapai garis finis terlebih dahulu dari regu lain, dinyatakan sebagai pemenangnya. Pertandingan pacu jalur biasanya dilakukan dengan sistem gugur untuk menentukan pemenang pertama hingga ke empat dan sepuluh besar, diawali dengan membunyikan meriam. Meriam digunakan karena apabila memakai peluit tidak akan terdengar oleh peserta lomba, mengingat luasnya arena pacu dan banyaknya penonton yang menyaksikan perlombaan. Pada dentuman pertama jalurjalur yang telah ditentukan urutannya akan berjejer di garis start dengan anggota setiap regu telah berada di dalam jalur. Pada dentuman kedua, mereka akan berada dalam posisi siap (berjaga-jaga) untuk mengayuh dayung, dan setelah wasit membunyikan meriam untuk yang ketika kalinya, maka setiap regu akan bergegas mendayung melalui jalur lintasan yang telah ditentukan ${ }^{6}$.

Oleh karena pacu jalur adalah salah satu olahraga tradisional yang dikenal dari Provinsi Riau yaitu daerah Kuantan Singingi. Maka tradisi pacu jalur merupakan salah satu kebudayaan daerah yang dipandang perlu untuk dilindungi dan dilestarikan.

Dalam tulisan ini mencoba mengkaji konsep perlindungan pacu jalur dari Kabupaten Kuantan Singingi.

\section{B. METODE PENELITIAN}

Jenis penelitian yang digunakan yaitu yuridis normatif dengan pendekatan peraturan perundang-undangan (statutory approach) dan pendekatan kasus (case approach). Penelitian juga mengkaji substansi hukum terkait dengan pelestarian warisan budaya Melayu di Siak berdasarkan aturan hukum yang berlaku. Teknik pengumpulan melakukan studi kepustakaan dengan menkaji aturan hukum terkait dengan warisan budaya. Data yang diperoleh dianalisis melalui kualitatif dan tidak menutup kemungkinan data kuantitatif yang

${ }^{5}$ Ibid.

${ }^{6}$ Ibid. 
berfungsi untuk mengarahkan dan mempertajam analisis kualitatif.Metode penelitian berisi hal-hal berikut: spesifikasi penelitian, Jenis penelitian, metode penelitian, metode pendekatan, teknik pengumpulan data, dan metode analisis data. Metode penelitian ditulis secara deskriptif.

\section{HASIL DAN PEMBAHASAN}

Negara sebagai otoritas tertinggi, sehingga Negara mempunyai fungsi untuk memberikan perlindungan hukum dengan membentuk peraturan perundang-undangan. Pembahasan perlindungan hukum yang berkaitan dengan pacu jalur yang merupakan juga kebudayaan dari Kabupaten Kuantan Singingi maka perlindungan hukum yang dapat diberikan yaitu sebagai warisan budaya yaitu warisan budaya tak benda dan kekayaan intelektual terutama dalam lingkup kerangka intelektual komunal.

Menurut Muchsin dalam tulisan Dr. Dyah Permata Budi Asri., S.H., M.Kn disebutkan bahwa sarana dalam perlindungan hukum terbagi atas perlindungan hukum preventif yaitu perlindungan yang diberikan oleh pemerintah dengan tujuan untuk mencegah sebelum terjadinya pelanggaran. Hal ini terdapat dalam peraturan perundangundangan dengan maksud untuk mencegah suatu pelanggaran serta memberikan rambu-rambu atau batasan-batasan dalam melakukan suatu kewajiban. Kedua perlindungan hukum represif merupakan perlindungan akhir berupa sanksi seperti denda, penjara, dan hukuman tambahan yang diberikan apabila sudah terjadi sengketa atau telah dilakukan suatu pelanggaran $^{7}$.

Warisan budaya dari suatu Negara perlu dilindungi untuk menghindari kepunahan. Dan negaralah yang berperan untuk memberikan perlindungan tersebut. Negara dapat memberikan perlindungan hukum atas warisan budaya bangsa Indonesia. Menurut Prof. Satjipto Rahardjo dalam tulisan tulisan Dr. Dyah Permata Budi Asri., S.H., M.Kn, perlindungan hukum memberikan pengayoman kepada hak asasi manusia yang dirugikan orang lain dan perlindungan tersebut diberikan kepada masyarakat agar mereka dapat menikmati semua hak-hak yang diberikan oleh hukum atau dengan kata lain perlindungan hukum adalah berbagai upaya hukum yang harus diberikan oleh aparat penegak hukum untuk memberikan rasa aman, baik secara pikiran maupun fisik dari gangguan dan berbagai ancaman dari pihak manapun ${ }^{8}$.

\footnotetext{
${ }^{7}$ Ibid.

8 Asri, D.A.B. (2018). Perlindungan Hukum Preventif Terhadap Ekspresi Budaya Tradisional di Daerah Istimewa Yogyakarta Berdasarkan UndangUndang Nomor 28 Tahun 2014. Journal of Intellectual Property, h.16.
} 
Dalam tulisan ini konsep perlindungan yang dibahas yaitu perlindungan hukum preventif yaitu dengan melihat dari peraturan perundanganundangan terkait. Dasar awal perlindungan untuk pacu jalur dari Kabupaten Kuansing bisa dilihata dalam Undang-Undang Dasar Negara Republik Indonesia Tahun 1945. Dalam Pasal 32 menyebutkan bahwa Negara memajukan kebudayaan Nasional Indonesia di tengah peradaban dunia dengan menjamin kebebasan masyarakat dalam memelihara dan mengembangkan nilai budayanya. Pacu jalur merupakan salah satu contoh kebudayaan Nasional Indonesia yang telah mengakar di Kabupaten Kuantan Singingi. Tradisi pacu jalur adalah tradisi yang telah mengakar lama bagi masyarakat Kuantan Singingi. Jalur merupakan suatu hasil budaya, yang dikenal baik dalam masyarakat rantau Kuantan, dalam kurun waktu yang cukup lama, seperti yang diuraikan dalam pendahuluan bahwa tradisi pacu jalur ini telah ada sejak zaman penjajahan Belanda.

Dasar perlindungan selanjutnya dapat ditemui dalam Undang - Undang Nomor 18 Tahun 2002 tentang Sistem Nasional Penelitian, Pengembangan dan Penerapan Ilmu Pengetahuan dan Teknologi. Dalam aturan hukum ini menyebutkan bahwa Pemerintah menjamin perlindungan bagi pengetahuan dan kearifan lokal, nilai budaya asli masyarakat, serta kekayaan hayati dan non-hayati di Indonesia ${ }^{9}$. Selanjutnya dalam UndangUndang Nomor 11 Tahun 2005 tentang Pengesahan Konvenan Internasional tentang Hak-Hak Ekonomi, Sosial dan Budaya. Aturan hukum tentang pengesaha perjanjian internasional yang diikuti oleh Indonesia ini mengatur terkait hak untuk ikut serta dalam kehidupan budaya pada masyarakat.

Tahun 2017, Pemerintah mengeluarkan Undang-Undang Nomor 5 Tahun 2017 tentang Pemajuan Kebudayaan. Pemajuan kebudayaan adalah upaya meningkatkan ketahanan budaya dan kontribusi budaya Indonesia di tengah peradaban dunia melalui Perlindungan, Pengembangan, Pemanfaatan dan Pembinaan Kebudayaan. Pemajuan Kebudayaan dilaksanakan berdasarkan pada Pokok Pikiran Kebudayaan, Strategi Kebudayaan berupa adalah dokumen dengan arah Pemajuan Kebudayaan yang berlandaskan pada potensi, situasi, dan kondisi Kebudayaan Indonesia untuk mewujudkan tujuan nasional, serta Rencana Induk Pemajuan Kebudayaan yakni pedoman bagi Pemerintah Pusat dalam melaksanakan Pemajuan Kebudayaan.

Peraturan Presiden Nomor 78 Tahun 2007 tentang Pengesahan Convention for The Safeguarding of The Intangible

\footnotetext{
${ }^{9}$ Pasal 23
} 
Cultural Heritage (Konvensi untuk Perlindungan Warisan Budaya Takbenda). Peraturan Presiden ini merupakan aturan hukum untuk memberlakukan Perjanjian Internasional terkait dengan perlindungan warisan budaya takbenda. Dalam Perjanjian Internasional ini mendefinisikan warisan budaya tidak berwujud sebagai praktikpraktik, ekspresi-ekspresi serta pengetahuan dan keahlian yang diakui oleh komunitas/masyarakat, kelompok dan dalam beberapa kasus secara individu sebagai bagian dari warisan budaya ${ }^{10}$.

Tujuan utama yang ingin dicapai oleh Konvensi ini adalah kelestarian budaya sebagai warisan bersama. Konvensi ini tidak menggunakan istilah "protection" melainkan "safeguarding" sebagai istilah perlindungan. Berdasarkan Pasal 2 ayat (3), yang dimaksud "safeguarding" ialah upaya atau tindakan yang bertujuan untuk menjamin kelestarian warisan budaya tak benda. Pasal 19 ayat (2) juga mempertegas bahwa tujuan dibentuknya perjanjian ini ialah untuk kepentingan kemanusiaan secara umum. Jadi, kebebasan versi perjanjian ini bukanlah untuk kepentingan industrial, tetapi sebaliknya, untuk kepentingan pemanusiaan seluruh umat manusia. $^{11}$

${ }^{10}$ Pasal 2 Ayat 1 dan 2 UNESCO Convention For The Safeguarding Of The Intangible Cultural Heritage, 2003.

11 Miranda Risang Ayu, Rika Ratna Permata, Laina Rafianti, "Sistem Perlindungan Sumber Daya
Peraturan Presiden Nomor 78 Tahun 2011 tentang Pengesahan Convention on the Protection and Promotion of the Diversity of Cultural Expressions (Konvensi tentang Proteksi dan Promosi Keanekaragaman Ekspresi Budaya. Peraturan Presiden ini merupakan aturan hukum untuk memberlakukan Perjanjian Internasional terkait dengan proteksi dan promosi keanekaragaman ekspresi budaya. Keanekaragaman budaya adalah kekuatan pendorong pembangunan, tidak hanya dalam hal pertumbuhan ekonomi, tetapi juga sebagai sarana menjalani kehidupan intelektual, emosional, moral dan spiritual yang lebih memuaskan. Hal ini terlihat dari tujuh konvensi budaya, yang memberikan dasar kokoh untuk promosi keanekaragaman budaya. Dengan demikian keanekaragaman budaya merupakan aset yang diperlukan dalam rangka untuk pengurangan kemiskinan dan pencapaian pembangunan berkelanjutan.

Menjaga keanekaragaman ekspresi budaya merupakan tantangan bagi masyarakat lokal, nasional dan internasional saat ini. Untuk mengatasi dimensi tertentu dari keragaman budaya, Negara Anggota UNESCO mengadopsi Konvensi tentang Perlindungan dan Promosi Keanekaragaman Ekspresi Budaya

Tak Benda di Palembang, Sumatera Selatan Indonesia", Jurnal Mimbar Hukum, Universitas Padjajaran, Vol.29 No.2, Juni 2017, hlm.212. 
pada tahun 2005. Program ini menitikberatkan pada kesepakatan internasional dalam memastikan seniman dan aktivis kebudayaan serta masyarakat dapat menciptakan, memproduksi dan menyebarluaskan dan menikmati berbagai barang budaya. Seiring dengan berjalannya waktu, memastikan Sekretariat Konvensi UNESCO mendesain ulang proyek operasional dan mengelaborasi program baru agar dapat berkontribusi untuk mencapai tujuan dari Konvensi.

Upaya melindungi warisan budaya tak benda tentu juga melibatkan peranan pemerintah daerah. Bentuk dari peranan pemerintahan daerah salah satunya ialah mendorong serta melindungi warisan budaya tak benda, dengan cara menyediakan ruang fisik dan sarana keuangan yang diperlukan untuk pertunjukkan musikal, prosesi, festival, dan sebagainya. $^{12}$

Peraturan Menteri Dalam Negeri Nomor 52 Tahun 2007 tentang Pedoman Pelestarian dan Pengembangan Adat Istiadat dan Nilai Sosial Masyarakat. Pelestarian dan pengembangan adat istiadat dan nilai sosial budaya masyarakat yang dimaksudkan untuk memperkokoh jati diri

12 Janet Blake, "Seven Years of Implemeting UNESCO's 2003 Intangible Heritage Convention Honeymoon Period of the seven-years itch?", Cambridge University Press, Vol 21 No. 3 Maret 2014, hlm.3., Diunduh dari: https://1.next.westlaw.com/Document/ diakses tanggal, 08 Desember 2017. individu dan masyarakat dalam mendukung kelancaran penyelenggaraan pemerintahan dan pembangunan yang bertujuan untuk mendukung pengembangan budaya nasional dalam mencapai peningkatan kualitas ketahanan nasional dan keutuhan Negara Kesatuan Republik Indonesia. Menurut peraturan ini, pelestarian dan pengembangan adat istiadat dan nilai sosial budaya masyarakat dilakukan dengan konsep, program dasar, dan strategi pelaksanaan.

Peraturan Bersama Menteri Dalam Negeri dan Menteri Kebudayaan dan Pariwisata Nomor 42 Tahun 2009 dan Nomor 40 Tahun 2009 tentang Pedoman Pelestarian Kebudayaan. Dalam peraturan ini menyebutkan bahwa Pemerintah Daerah melaksanakan pelestarian kebudayaan daerah. Kegiatan pelestarian kebudayaan dilakukan melalui perlindungan, pengembangan dan pemanfaatan. Pelestarian kebudayaan meliputi aspekaspek kesenian, kepurbakalaan, kesejarahan, permuseuman, kebahasaan, kesusastraan, tradisi, kepercayaan kepada Tuhan Yang Maha Esa, kepustakaan, kenaskahan, dan perfilman.

Peraturan Menteri Pendidikan dan Kebudayaan Nomor 106 Tahun 2013 tentang Warisan Budaya Tak Benda Indonesia. Menurut peraturan menteri ini bahwa dalam rangka pelestarian warisan budaya tak benda, Pemerintah berkewajiban 
melakukan pencatatan dan penetapan warisan budaya tak benda yang ada di wilayah Negara Kesatuan Republik Indonesia. Kategori warisan budaya tak benda di Indonesia yaitu tradisi dan ekspresi lisan; seni pertunjukan; adatistiadat masyarakat, ritus, dan perayaanperayaan; pengetahuan dan kebiasaan perilaku mengenai alam dan semesta; keterampilan dan kemahiran tradisional. Penetapan warisan budaya tak benda Indonesia bertujuan untuk melestarikan warisan budaya tak benda Indonesia; meningkatkan harkat dan martabat bangsa; memperkuat karakter, identitas, dan kepribadian bangsa; mempromosikan warisan budaya tak benda Indonesia kepada masyarakat luas; meningkatkan kesejahteraan rakyat. Pemerintah dan Pemerintah Daerah berkewajiban menjamin pelestarian warisan budaya tak benda Indonesia melalui program peningkatan kesadaran Pelestarian. Pemerintah dan Pemerintah Daerah mempunyai rencana aksi dalam melestarikan warisan budaya tak benda Indonesia.

Pembentukkan Peraturan Menteri Pendidikan dan Kebudayaan Republik Indonesia Nomor 106 Tahun 2013 tentang Warisan Budaya Tak Benda ini merupakan wujud dari komitmen Indonesia yang telah meratifikasi Konvensi Perlindungan Warisan Budaya Tak Benda Convention For The Safeguarding of The Intangible
Cultural Heritage, yang lebih dikenal dengan Konvensi UNESCO (United Nations, Educational, Scientific, and Cultural Organization) Tahun 2003. Konvensi ini diratifikasi oleh Indonesia dengan Peraturan Presiden Republik Indonesia Nomor 78 Tahun 2007 tentang pengesahan Convention For The Safeguarding of The Intangible Cultural Heritage (konvensi untuk perlindungan warisan budaya tak benda). Konvensi UNESCO Tahun 2003, telah diratifikasi oleh 127 negara pada bulan Juli 2010. ${ }^{13}$

Konvensi UNESCO Tahun 2003 ini menyoroti unsur-unsur utama warisan budaya tak benda dan didasarkan pada dasar pemikiran filosofis yang tepat. ${ }^{14}$ Konvensi ini menetapkan karakteristik budaya yang telah dikategorikan sebagai warisan budaya tak benda, yang antara lain dapat ditularkan antar generasi, berkembang secara dinamis, menyatu dengan identitas komunitas serta merupakan sumber kreativitas. ${ }^{15}$

\footnotetext{
${ }^{13}$ Lucas Lixinski, "Selecting Heritage: The Interplay of Art, Politics And Identity", European Journal of International Law, Vol. 22 No. 81 February 2011, hlm.2. Diunduhdari:https://1.next.westlaw.com/Document/i de9fa936670411e08b05fdf15589d838/Viev/ Full Text. Html. diakses Tanggal, 08 Desember 2017.

${ }^{14}$ Federico Lenzerini "Intangible Cultural Heritage: The Living Cultur Of Peoples", European Journal of International Law, Vol.22 No. 101 February 2011, hlm. 1. Diunduh dari: http://1.next.westlaw.co,/Document/ diakses tanggal 28 Januari 2018.

${ }^{15}$ Zainul Daulay, Pengetahuan Tradisional, PT RajaGrafindo Persada, Jakarta: 2011, hlm. 19.
} 
Tradisi pacu jalur dapat dilindungi oleh Konvensi UNESCO Tahun 2003 Karena tradisi pacu jalur telah memenuhi persyaratan yang telah diamanahkan oleh Pasal 2 ayat (1) Konvensi UNESCO Tahun 2003 tersebut, yang antara lain ialah:

1. Diwariskan dari generasi ke generasi;

2. Secara terus-menerus diciptakan kembali oleh berbagai komunitas dan kelompok sebagai tanggapan mereka terhadap lingkungannya;

3. Interaksi dengan alam, serta sejarahnya;

4. Memberikan mereka makna jati diri dan keberlanjutan;

5. Untuk memajukan penghormatan keanekaragaman budaya dan kreatifitas manusia.

Salah satu implementasi dari perlindungan terhadap warisan budya tak benda yaitu dengan melakukan inventarisasi terkait dengan warisan budaya. Setelah Indonesia mengesahkan Convention for the Safeguarding of Intangible Cultural Herritage tahun 2003, maka Indonesia wajib untuk melakukan pencatatan karya budaya dari seluruh Indonesia yang merupakan wujud dari perlindungan hukum oleh Negara. Maka Direktorat Warisan dan Diplomasi Budaya melakukan penetapan waisan budaya tak benda (WBTB) Indonesia. Penetapan warisan budaya tak benda Indonesia adalah pemberian status budaya tak benda menjadi warisan budaya tak benda Indonesia oleh Menteri berdasarkan rekomendasi tim ahli warisan budaya tak benda Indonesia ${ }^{16}$.

Kegiatan penetapan dilakukan sebagai upaya untuk perlindungan dan pelestarian budaya tak benda yang ada di wilayah Negara Kesatuan Republik Indonesia yang melibatkan Pemerintah Pusat, Pemerintah Daerah, setiap orang dan masyarakat hukum adat ${ }^{17}$. Kegiatan penetapan warisan budaya tak benda bertujuan menjamin dan melindungi warisan budaya tak benda yang merupakan milik berbagai komuniti, kelompok, dan perseorangan yang bersangkutan; meningkatkan harkat dan martabat bangsa serta memperkuat karakter, identitas dan kepribadian bangsa; meningkatkan apresiasi dan kebanggaan masyarakat Indonesia terhadap keunikan dan kekayaan ragam budaya Indonesia; meningkatkan kesadaran dan peran aktif masyarakat dan pemangku kebijakan terhadap pentingnya warisan budaya tak benda; serta saling menghargai terhadap warisan budaya bangsa; mempromosikan warisan budaya tak benda

\footnotetext{
16 Direktorat Warisan dan Diplomasi Budaya Direktorat Jenderal Kebudayaan Kementerian Pendidikan dan Kebudayaan. (2018). Penetapan Warisan Budaya Tak Benda Indonesia Tahun 2018. Jakarta : Direktorat Warisan dan Diplomasi Budaya Direktorat Jenderal Kebudayaan Kementerian Pendidikan dan Kebudayaan, h.iv.

17 Ibid.
} 
Indonesia kepada masyarakat luas dan meningkatkan kesejahteraan ${ }^{18}$.

Tahapan pelaksanaan kegiatan penetapan warisan budaya tak benda yaitu $^{19}$ :

1. Pertemuan Pemangku Kepentingan Warisan Budaya Tak Benda;

Kegiatan ini dilaksanakan pada awal seluruh kegiatan penetapan untuk mensosialisasikan pentingnya pelestarian warisan budaya tak benda kepada semua masyarakat, baik pemangku kepentingan (stakeholder), komunitas, swasta, maupun masyarakat umum. Tujuan lain adalah agar terjalin komunikasi serta koordinasi yang baik antara Pemerintah Pusat maupun Pemerintah Daerah dan pihak-pihak terkait.

2. Rapat Penilaian Warisan Budaya Tak Benda;

Rapat penilaian dilakukan sebanyak tiga kali. Rapat -rapat ini membahas dan memeriksa usulan karya budaya yang telah masuk ke Sekretariat WBTB oleh tim ahli dan narasumber warisan budaya tak benda. Tim ahli warisan budaya tak benda Indonesia adalah ahli-ahli di bidang kebudayaan yang dibentuk dan ditetapkan oleh Menteri melalui

\footnotetext{
18 Ibid, h.v.
}

${ }^{19}$ Ibid, h,v-vi.
Surat Keputusan Menteri untuk melakukan penilaian dan memberikan rekomendasi penetapan warisan budaya tak benda Indonesia.

3. Verifikasi Data Warisan Budaya Tak Benda;

Data kekayaan budaya yang telah didaftarkan akan diverifikasi dan dilakukan penilaian oleh tim ahli. Dalam melakukan verifikasi, tim ahli membawa berkas-berkas kelengkapan data yang dimiliki oleh tim kesektariatan pusat. Tim ahli kemudian turun ke daerah masingmasing karya budaya itu berasal untuk memverifikasi data-data usulan karya budaya yang ada. Bila ada data-data yang kurang atau tidak sesuai dengan kenyataan yang ada, maka tim ahli berhak untuk melengkapi atau menunda proses penetapan.

4. Sidang Penetapan Warisan Budaya Tak Benda Indonesia;

Sidang penetapan adalah tahap akhir penilaian karya budaya yang telah melalui serangkaian tahapan persyaratan penetapan warisan budaya tak benda. Melalui sidang penetapan ini seluruh usulan karya budaya akan ditentukan statusnya apakah ditetapkan sebagai warisan budaya tak benda Indonesia atau 
ditangguhkan. Sidang dihadiri oleh Kepala Dinas atau para perwakilan dari seluruh Provinsi yang telah mengajukan usulan warisan budaya tak benda Indonesia.

5. Apresiasi Penetapan Warisan Budaya Tak Benda.

Karya budaya yang telah ditetapkan sebagai warisan budaya tak benda Indonesia kemudian disahkan oleh Menteri melalui SK Penetapan Warisan Budaya Tak Benda Indonesia yang dicantumkan Sertifikat Warisan Budaya Tak Benda Indonesia. Sertifikat penetapan kemudian diserahkan kepada Provinsi melalui Gubernur atau yang mewakilinya dalam Kegiatan Apresiasi Penetapan Warisan Budaya Tak Benda Indonesia.

Peraturan Menteri Pendidikan dan Kebudayaan Nomor 10 Tahun 2014 tentang Pedoman Pelestarian Tradisi. Dalam aturan hukum ini, menyebutkan bahwa pelestarian tradisi adalah upaya perlindungan, pengembangan, dan pemanfaatan, suatu kebiasaan dari kelompok masyarakat pendukung kebudayaan yang penyebaran dan pewarisannya berlangsung secara turun temurun. Adapun objek pelestarian tradisi meliputi upacara tradisional yaitu peristiwa sacral yang berkaitan dengan kekuatan di luar kemampuan manusia (gaib) dengan peristiwa alam dan daur hidup; cerita rakyat yaitu cerita yang disebarluaskan dan diwariskan secara lisan dan digolongkan menjadi tiga kelompok besar yaitu mite, legenda dan dongeng; permainan rakyat yaitu suatu kegiatan reaktif yang memiliki aturan khusus yang merupakan cerminan karakter budaya serta berfungsi sebagai pemelihara hubungan sosial; ungkapan tradisional yaitu kalimat-kalimat kiasan, symbol-simbol yang dipahami maknanya oleh para pemakainya secara lisan dimana terkandung nilai-nilai kehidupan dan pandangan hidup masyarakat; pengobatan tradisional yaitu tata cara penyembuhan penyakit yang dilakukan secara tradisional dan diwariskan secara turun temurun dengan menggunakan peralatan tradisional serta memanfaatkan bahan yang diperoleh dari lingkungan alam dan penggunaan mantra; makanan dan minuman tradisional yaitu jenis makan dan minuman yang berbahan baku alami dan proses pembuatannya masih menggunakan alatalat sederhana serta merupakan suatu hasil karya budaya masyarakat lokal tertentu; arsitektur tradisional yaitu suatu bangunan yang bentuk, struktur, fungsi, ragam bias, dan cara membuatnya diwariskan dari satu generasi ke generasi berikutnya serta dapat dimanfaatkan sebagai tempat untuk melaksanakan aktivitas kehidupan; pakaian tradisional yaitu busana yang berfungsi untuk melindungi tubuh dari lingkungan 
alam, serta memiliki nuansa kedaerahan yang menjadi ciri khas atau identitas bagi masyarakat pendukungnya; kain tradisional yaitu kain yang bahan bakunya masih mengandalkan sumber alam dan proses pembuatannya masih menggunakan alatalat sederhana serta merupakan suatu hasil karya budaya masyarakat lokal tertentu; peralatan hidup yaitu segala sesuatu yang digunakan untuk mempermudah pemenuhan kebutuhan hidup manusia; senjata tradisional yaitu alat yang digunakan untuk mempertahankan diri dari serangan/ ancaman dari serangan/ ancaman dari segala sesuatu dan kelengkapan identitas yang cara pembuatannya, bentuknya dan penggunaannya diwariskan secara turun-temurun; dan atau/; organisasi sosial tradisional yaitu perkumpulan sosial yang dibentuk oleh masyarakat tradisional, yang memiliki seperangkat sistem yang mengikat keanggotaannya.

Menurut Bouwman- Noor Mout menyatakan kekayaan intelektual merupakan hasil kegiatan berdaya cipta pikiran manusia yang diungkapkan ke dunia luar dalam suatu bentuk, baik materil maupun immaterial. Bukan bentuk penjelmaannya yang dilindungi, melainkan daya cipta itu sendiri, Daya cipta itu dapat berwujud dalam bidang seni, industry dan ilmu pengetahuan dan paduan ketiga- tiganya $^{20}$. John $\mathrm{E}$ Williams menyatakan pendapatnya mengenai hak atas kekayaan intelektual yaitu the term intellectual property seems to be the best available to cover that body of the legal rights which arise from mental and artistic endeavor ${ }^{21}$. David I Bainbridge mengatakan bahwa Intellectual Property is the collective name given to legal rightswhich protect the product of the human intellect ${ }^{22}$. World Intellectual Property Organization (WIPO) memberikan defenisi untuk Hak Kekayaan Intelektual yaitu kreasi yang dihasilkan pikiran manusia yang meliputi : invensi, karya sastra dan seni, simbol, nama, citra dan desain yang digunakan dalam perdagangan $^{23}$.

Kekayaan Intelektual Komunal merupakan kekayaan intelektual yang kepemilikannya bersifat kelompok, merupakan warisan budaya yang menjadi identitas suatu kelompok atau masyarakat. Kekayaan Intelektual Komunal didefinisikan sebagai Kekayaan Intelektual berupa Pengetahuan Tradisional (PT), Ekspresi Budaya Tradisional (EBT),

\footnotetext{
${ }^{20}$ Rosidawati,I. Munzil. F. Pengetahuan Tradisional \& Hak Kekayaan Intelektual : Perlindungan Pengetahuan Tradisional Berdasarkan Asas Keadilan melalui Sui Generis Intellectual Property System. Bandung : PT. Refika Aditama, h. 31.

${ }^{21} \mathrm{Ibid}$, h. 30

${ }^{22}$ Ibid.

${ }^{23}$ Utomo. T.S. (2010). Hak Kekayaan Intelektual (HKI) di Era Global : Sebuah Kajian Kontemporer. Yogyakarta : Graha Ilmu, h. 1.
} 
Sumber Daya Genetik (SDG), dan Potensi Indikasi Geografis.

Ekspresi budaya tradisional dapat didefenisikan sebagai hasil aktivitas intelektual, pengalaman, atau pemahaman, yang diekspresikan oleh masyarakat adat dalam konteks tradisi, yang sifatnya dinamis dan dapat mengalami perkembangan, termasuk di dalamnya ekspresi dalam bentuk kata-kata, musik, gerakan, ekspresi dalam bentuk benda atau takbenda, atau gabungan dari bentukbentuk tersebut ${ }^{24}$. Untuk pengetahuan tradisional dapat didefenisikan sebagai pengetahuan yang berasal dari masyarakat adat, yang dapat bersifat dinamis dan berkembang serta merupakan hasil dari aktivitas intelektual, pengalaman, pengalaman spiritual, atau pemahaman dalam konteks tradisi - dan dapat berkaitan dengan tanah dan lingkungan - termasuk pengetahuan praktis, keahlian, inovasi, praktik, pengajaran, atau pembelajaran ${ }^{25}$. Undang - Undang Nomor 28 Tahun 2014 tentang Hak Cipta, salah aturan terkait kekayaan intelektual komunal. Dalam aturan ini, mengatur terkait hak yang terkanudng dalam warisan budaya yaitu terkait dengan ekspresi budaya tradisional. Ekspresi budaya tradisional diatur dalam

24 Direktorat Jenderal Kekayaaan Intelektual Kementerian Hukum dan HAM RI. (2019). Modul Kekayaan Intelektual Bidang Kekayaan Intelektual Komunal. Jakarta : Direktorat Jenderal Kekayaaan Intelektual Kementerian Hukum dan HAM RI, h.10.

${ }^{25}$ Ibid, h. 12.
Bab V Undang-Undang Nomor 28 Tahun 2014. Pada bagian kesatu dipaparkan tentang ekspresi budaya tradisional dan Hak Cipta yang penciptanya tidak diketahui. Hak Cipta atas ekspresi budaya tradisional dipegang oleh Negara. Negara wajib menginventarisasi, menjaga dan memelihara ekspresi budaya tradisional. Penggunaan ekspresi budaya tradisional yang hak ciptanya dipegang oleh Negara, harus memperhatikan niai-nilai yang hidup dalam masyarakat pengembannya.

Filosofi Hak Kekayaan Intelektual ${ }^{26}$ :

a. Utilitharian Theory (J.Bentham);

Aturan hak kekayaan intelektual untuk memberikan manfaat dan kesejahteraan sebanyak individuindividu dalam masyarakat (greatest happiness for greatest number).

b. Labour Theory (Jhon Locke);

Seseorang memiliki hak milik secara natural atas karya atau temuan karena tenaga kerja (waktu, tenaga dan pikiran).

c. Personality Theory (Kant, Hegel, J Hugest);

Hak milik terhadap karya intelektual karena karya cipta/temuan merupakan ekspresi cerminan pribadi pencipta.

\footnotetext{
${ }^{26}$ Roisah. Konsep Hak Kekayaan Intelektual (HKI) : Sejarah, Pengertian, dan Filosofi Pengakuan HKI dari Masa ke Masa. Malang : Setara, h. 19.
} 
d. Social Planing Theory ( Thomas J\& W Fisher)

Aturan hak kekayaan intelektual untuk penyebaran visi yang dapat memenuhi keinginan dan hasrat masyarakat lebih banyak.

Prinsip-prinsip dasar perlindungan kekayaan intelektual yaitu $^{27}$ :

a. Prinsip Keadilan (The Principle of Natural Justice)

Pencipta sebuah karya, atau orang lain yang membuahkan hasil dari kemampuan intelektualnya, wajar memperoleh imbalan. Imbalan tersebut dapat berupa materi maupun bukan materi seperti adanya rasa aman karena dilindungi, dan diakui hasil karyanya. Hukum memberikan perlindungan tersebut demi kepentingan pencipta berupa sesuatu kekuasaan untuk bertindak dalam rangka kepentingan tersebut, yang kita sebut sebagai hak.

b. Prinsip Ekonomi (The Economic Principle)

Hak kekayaan intelektual merupakan suatu bentuk kekayaan bagi pemiliknya. Dari kepemilikan tersebut mendapatkan keuntungan misalnya dalam pembayaran royalty, dan technical fee. c. Prinsip Kebudayaan (The Cultural Argument)

Karya manusia itu pada hakikatnya bertujuan untuk memungkinnya hidup, dari karya itu akan timbul gerak hidup yang menghasilkan lebih banyak karya lagi. Dengan demikian maka pertumbuhan dan perkembangan ilmu pengetahuan, seni sastra sangat besar bagi peningkatan taraf kehidupan, peradaban dan martabat manusia, serta juga memberikan kemashalatan bagi masyarakat bangsa dan Negara.

d. Prinsip Sosial (The Social Argument)

Hak apapun yang diakui oleh oleh hukum, yang diberikan kepada perseorangan, persekutuan atau kesatuan yang tidak boleh sematamata untuk kepentingan mereka saja tetapi juga kepentingan seluruh masyarakat.

Bentuk kepemilikan Kekayaan Intelektual dibagi dua yaitu Kepemilikan Personal dan Kepemilikan Komunal. ${ }^{28}$ Warisan budaya Indonesia merupakan bagian dari Kekayaan Intelektual Komunal (KIK) yang dimiliki Indonesia. Kekayaan Intelektual Komunal merupakan kekayaan intelektual yang kepemilikannya bersifat

${ }^{28}$ Direktorat Jenderal...Op.Cit, h.3. 
kelompok, merupakan warisan budaya yang menjadi identitas suatu kelompok atau masyarakat. Kekayaan Intelektual Komunal didefinisikan sebagai Kekayaan Intelektual berupa Pengetahuan Tradisional (PT), Ekspresi Budaya Tradisional (EBT), Sumber Daya Genetik (SDG), dan Potensi Indikasi Geografis. Dasar hukum kekayaan intelektual komunal yaitu :

1. Undang-Undang Republik Indonesia Nomor 11 tahun 2013 tentang Pengesahan Nagoya Protocol on Access to Genetic Resources and the Fair and Equitable Sharing of Benefits Arising from Their Utilization to the Convention on Biological Diversity;

2. Undang-Undang Republik Indonesia Nomor 28 Tahun 2014 tentang Hak Cipta;

3. Undang-Undang Republik Indonesia Nomor 20 Tahun 2016 tentang Merek dan Indikasi Geografis;

4. Undang-Undang Republik Indonesia Nomor 13 Tahun 2016 tentang Paten;

5. Undang-Undang Republik Indonesia Nomor 11 tahun 2019 tentang Sistem Nasional Ilmu Pengetahuan Dan Teknologi;

6. Peraturan Pemerintah Republik Indonesia Nomor 48 Tahun 2011 tentang Sumber Daya Genetik Hewan dan Perbibitan Ternak;

7. Peraturan Menteri Pertanian Nomor: 67/Permentan/OT.140/12/2006 tentang
Pelestarian dan Pemanfaatan Sumber Daya Genetik Tanaman;

8. Peraturan Menteri Hukum dan Hak Asasi Manusia Nomor 13 tahun 2017 tentang Data Kekayaan Intelektual Komunal;

9. Peraturan Menteri Lingkungan Hidup Dan Kehutanan Republik Indonesia Nomor

P.2/Menlhk/Setjen/Kum.1/1/2018

Tentang Akses Pada Sumber Daya Genetik Spesies Liar Dan Pembagian Keuntungan Atas Pemanfaatannya.

Ekspresi budaya tradisional dapat didefenisikan sebagai hasil aktivitas intelektual, pengalaman, atau pemahaman, yang diekspresikan oleh masyarakat adat dalam konteks tradisi, yang sifatnya dinamis dan dapat mengalami perkembangan, termasuk di dalamnya ekspresi dalam bentuk kata-kata, musik, gerakan, ekspresi dalam bentuk benda atau takbenda, atau gabungan dari bentukbentuk tersebut ${ }^{29}$. Untuk pengetahuan tradisional dapat didefenisikan sebagai pengetahuan yang berasal dari masyarakat adat, yang dapat bersifat dinamis dan berkembang serta merupakan hasil dari aktivitas intelektual, pengalaman, pengalaman spiritual, atau pemahaman dalam konteks tradisi - dan dapat berkaitan dengan tanah dan lingkungan - termasuk

\footnotetext{
${ }^{29}$ Ibid, h. 10 .
} 
pengetahuan praktis, keahlian, inovasi, praktik, pengajaran, atau pembelajaran ${ }^{30}$.

\section{PENUTUP}

Pacu jalur merupakan salah satu tradisi dari Kabupaten Kuantan Singingi Provinsi Riau. Pacu jalur juga termasuk dalam ruang lingkup kebudayaan. Untuk ada kelestarian kebudayaan tentunya harus ada perlindungan terhadap kebudyaannya. Pelestarian tersebut perlu dituangkan dalam peraturan perundang-undangan yang jelas.

\footnotetext{
${ }^{30}$ Ibid, h. 12.
} 


\section{DAFTAR PUSTAKA}

Asri, D.A.B. (2018). Perlindungan Hukum Preventif Terhadap Ekspresi Budaya Tradisional di Daerah Istimewa Yogyakarta Berdasarkan Undang-Undang Nomor 28 Tahun 2014. Journal of Intellectual Property

Direktorat Jenderal Kekayaaan Intelektual Kementerian Hukum dan HAM RI. (2019). Modul Kekayaan Intelektual Bidang Kekayaan Intelektual Komunal. Jakarta : Direktorat Jenderal Kekayaaan Intelektual Kementerian Hukum dan HAM RI

Direktorat Warisan dan Diplomasi Budaya Direktorat Jenderal Kebudayaan Kementerian Pendidikan dan Kebudayaan. (2018). Penetapan Warisan Budaya Tak Benda Indonesia Tahun 2018. Jakarta : Direktorat Warisan dan Diplomasi Budaya Direktorat Jenderal Kebudayaan Kementerian Pendidikan dan Kebudayaan, h.iv

Federico Lenzerini "Intangible Cultural Heritage: The Living Cultur Of Peoples", European Journal of International Law, Vol.22 No. 101 February 2011

Hasbullah, dkk, Olahraga dan Magis: Kajian Terhadap Tradisi Pacu Jalur di Kabupaten Kuantan SIngingi, 2015

Janet Blake, "Seven Years of Implemeting UNESCO's 2003 Intangible Heritage
Convention -Honeymoon Period of the seven-years itch?", Cambridge University Press, Vol 21 No. 3 Maret 2014

Lucas Lixinski,"Selecting Heritage: The Interplay of Art, Politics And Identity", European Journal of International Law, Vol. 22 No. 81 February 2011

Miranda Risang Ayu, Rika Ratna Permata, Laina Rafianti, "Sistem Perlindungan Sumber Daya Tak Benda di Palembang, Sumatera Selatan Indonesia", Jurnal Mimbar Hukum, Universitas Padjajaran, Vol.29 No.2, Juni 2017

Roisah. Konsep Hak Kekayaan Intelektual (HKI) : Sejarah, Pengertian, dan Filosofi Pengakuan HKI dari Masa ke Masa. Malang : Setara

Rosidawati,I. Munzil. F. Pengetahuan Tradisional \& Hak Kekayaan Intelektual : Perlindungan Pengetahuan Tradisional Berdasarkan Asas Keadilan melalui Sui Generis Intellectual Property System. Bandung : PT. Refika Aditama

Utomo. T.S. (2010). Hak Kekayaan Intelektual (HKI) di Era Global : Sebuah Kajian Kontemporer. Yogyakarta : Graha Ilmu

UNESCO Convention For The Safeguarding Of The Intangible Cultural Heritage, 2003.

Zainul Daulay, Pengetahuan Tradisional, PT RajaGrafindo Persada, Jakarta: 2011 